\title{
Correction: Interactions of Isophorone Derivatives with DNA: Spectroscopic Studies
}

\author{
Marco Deiana, Katarzyna Matczyszyn, Julien Massin, Joanna Olesiak-Banska, \\ Chantal Andraud, Marek Samoc
}

The following information is missing from the Funding section: Wroclaw Centre of Biotechnology, Programme, The Leading National Research Centre (KNOW) provided funding for the publication of the results of the study.

\section{Reference}

1. Deiana M, Matczyszyn K, Massin J, Olesiak-Banska J, Andraud C, Samoc M (2015) Interactions of Isophorone Derivatives with DNA: Spectroscopic Studies. PLoS ONE 10(6): e0129817. doi:10.1371/ journal.pone.0129817 PMID: 26069963

\section{G openaccess}

Citation: Deiana M, Matczyszyn K, Massin J, Olesiak-Banska J, Andraud C, Samoc M (2015) Correction: Interactions of Isophorone Derivatives with DNA: Spectroscopic Studies. PLOS ONE 10(7): e0133814. doi:10.1371/journal.pone.0133814

Published: July 20, 2015

Copyright: @ 2015 Deiana et al. This is an open access article distributed under the terms of the Creative Commons Attribution License, which permits unrestricted use, distribution, and reproduction in any medium, provided the original author and source are credited. 